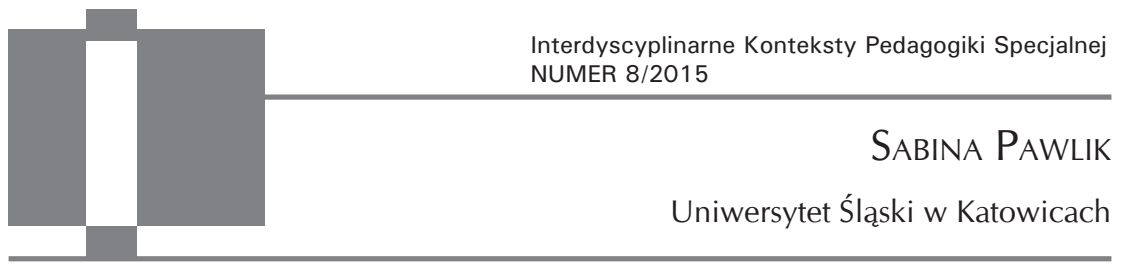

\title{
Sztuka jako sposób włączania osób z niepełnosprawnością intelektualną do społeczeństwa
}

\begin{abstract}
Aвstract: Pawlik Sabina, Art as a way of including people with intellectual disabilities into society [Sztuka jako sposób włączania osób z niepełnosprawnością intelektualną do społeczeństwa]. Interdyscyplinarne Konteksty Pedagogiki Specjalnej, nr 8, Poznań 2015. Pp. 59-74. Adam Mickiewicz University Press. ISBN 978-83-232-2902-5. ISSN 2300-391X.

Individuals with intellectual disabilities exist fully and authentically through works of art they have created. The universalism of the language of art happens to be for them a form of expression_ and, frequently, the only form of dialogue led with the outside world. Owing to art, an intellectually disabled person has a chance to go beyond the frames of his/her hermetic world. Art can be an import_ant stimulus influencing the social perception of individuals with intellectual disabilities. Furthermore, all the activities carried out in social, artistic and therapeutic fields can support the process of social inclusion of people with intellectual deficits.
\end{abstract}

KEY wORDs: inclusion, intellectual disability, art, theatre.

Znieczulica chamstwo

Średnio raz na parę dni

Ktoś mnie wrzuca do wora

Z imbecylami

Stawiając z idiotami w jednym rzędzie.

Ignoranci nie warci splunięcia. 


\section{Zamiast zrozumieć}

Że nie jesteśmy orłami intelektu

Dalej zaciskaja wokót nas

Te obręcz niezrozumienia

Pewnych uchybień.

Każdy człowiek jest inny.

Wywyższając się

Sami się zaniżacie.

Kto poniza

Sam jest niski.

Poniżanie niezrozumienie.

Marek Jankowski ${ }^{1}$

Rozważania na temat sztuki jako sposobu włączania osób z niepełnosprawnością intelektualną do społeczeństwa rozpoczęłam wierszem nadesłanym na I Przegląd Poezji Osób Niepełnosprawnych „Trzecia Przestrzeń" 2 . Jest to wypowiedź niepełnosprawnego intelektualnie twórcy, poruszająca temat społecznej segregacji i wyłączania osób z niepełnosprawnością z nurtu życia społecznego i kulturalnego. To głos sprzeciwu wobec zastanej rzeczywistości. Nie przypadkiem to właśnie język sztuki dał autorowi wiersza narzędzie do wyrażenia, a wręcz wykrzyczenia swojego buntu.

Tezą artykułu jest to, że twórczość (sztuka) może być sposobem społecznego włączania, rozumianego jako proces odzyskiwania dla społeczeństwa jednostek i całych grup środowiskowych, w tym przypadku osób z niepełnosprawnością intelektualną.

Dzięki uniwersalizmowi języka sztuki może ona stać się szansą na to, by głos osób z niepełnosprawnością intelektualną "choćby

${ }^{1}$ Marek Jankowski jest uczestnikiem Warsztatów Terapii Zajęciowej TPD w Sosnowcu, jako autor brał udział w projekcie „Trzecia Przestrzeń”, jego wiersz znalazł się w wyborze poezji I Przeglądu Poezji Osób Niepełnosprawnych „Trzecia Przestrzeń".

2 „Trzecia Przestrzeń” to projekt realizowany przez Stowarzyszenie Pomocy Niepełnosprawnym „Skarbek” w Mysłowicach, którego celem jest integracja środowiska lokalnego poprzez sztukę. 
początkowo wątły i nieśmiały, nieporadny"3 ${ }^{\prime 3}$ został usłyszany. Może stanowić to początek społecznej tolerancji, a w efekcie włączania osób niepełnosprawnych do społeczeństwa. Artyści niepełnosprawni intelektualnie istnieją bowiem w wytworzonych przez siebie dziełach w sposób pełny i autentyczny, a sztuka stanowi często jedyną formą dialogu, jaką prowadzą ze światem.

\section{Warunki obecności twórczości osób z niepełnosprawnością intelektualną w przestrzeni życia społecznego}

Aby twórczość osób z niepełnosprawnością intelektualną mogła zaistnieć w przestrzeni życia społecznego i kulturalnego, konieczny jest splot kilku czynników (schemat 1).

Zainteresowanie zjawiskiem. Problematyka twórczości osób z niepełnosprawnością intelektualną od wielu lat poruszana jest $\mathrm{w}$ literaturze $\mathrm{z}$ zakresu pedagogiki specjalnej. Wątki te są jednak rozproszone i przedstawiane w sygnalny sposób ${ }^{4}$. Refleksje na temat twórczości osób z niepełnosprawnością intelektualną przekraczają granice wypowiedzi pedagogicznej, wkraczając w rejony estetyki i sztuki. Pozbawiona własnej autonomii, zdaje się przynależeć do różnych dziedzin nauki: wiedzy o kulturze, pedagogiki, psychologii, socjologii, a także filozofii i medycyny. Rodzi to problemy natury metodologicznej, dopuszcza eklektyzm oraz fragmentaryczność analizy ${ }^{5}$. Trudno zatem o syntezujące studium z zakresu twórczości/ sztuki osób z niepełnosprawnością.

${ }^{3}$ D. Krzemińska, Kod językowy i dyskurs osób z niepetnosprawnością intelektualną. O bytowaniu na pograniczu, [w:] Świat pełen znaczeń, red. J. Baran, S. Olszewski, Kraków 2009, s. 574.

${ }^{4}$ K. Parys, Przestrzeń dla kreatywności uczniów z niepetnosprawnością intelektualna w stopniu lekkim, Impuls, Kraków 2013, s. 41.

${ }^{5}$ I. Jajte-Lewkowicz, Słowo wstępne, [w:] Terapia i teatr. Wokót problematyki ludzi niepetnosprawnych, red. I. Jajte-Lewkowicz, POS, Łódź 1999, s. 7. 


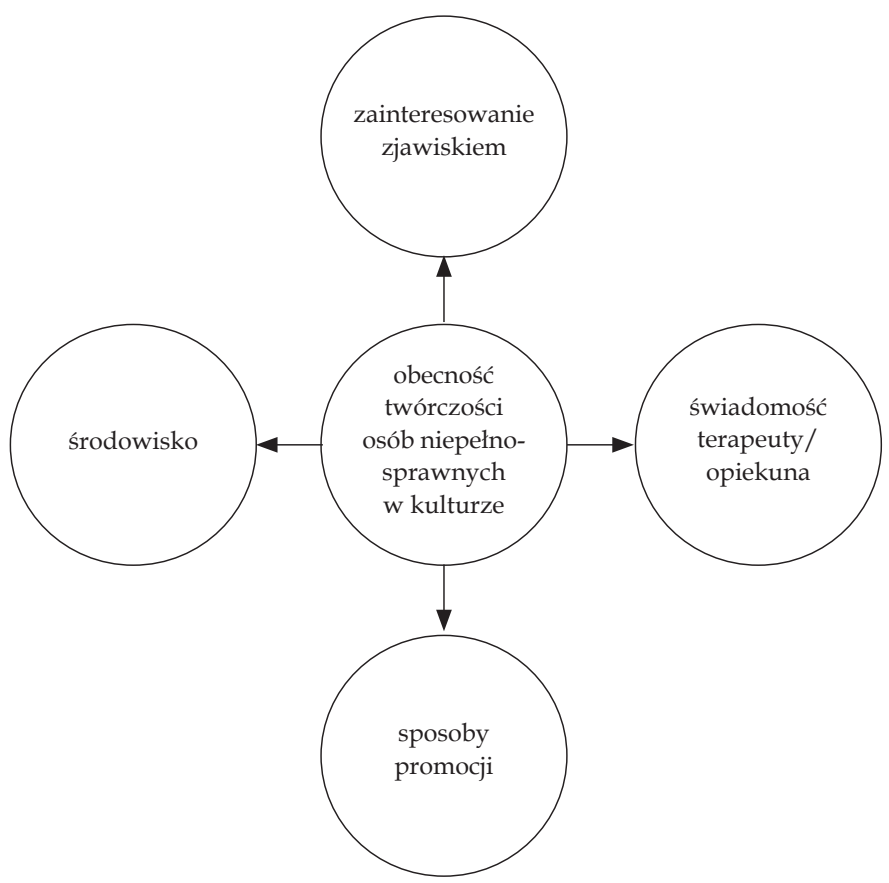

Schemat 1. Warunki obecności twórczości osób niepełnosprawnych w kulturze Źródło: opracowanie własne.

Podobnie dzieje się w obszarze szeroko pojętej aktywności twórczej. Odnajdziemy tam wiele sposobów na „praktykowanie twórczości”, począwszy od działań związanych z arteterapią, a skończywszy na otwartych formach działalności twórczej osób z niepełnosprawnością intelektualną.

Niezależnie od sposobu patrzenia na zjawisko twórczości osób z dysfunkcjami intelektualnymi warta podkreślenia jest aktywność osób i organizacji wspierających twórczość osób z niepełnosprawnością intelektualną - od zachwytu nad ich twórczością z perspektywy widza, poprzez różne działania wspomagające ich w procesie tworzenia, aż do promocji tej sztuki. 
Świadomość instruktora/opiekuna. Niezwykle ważną rolę w rozwoju twórczości osób z deficytami intelektualnymi odgrywa otoczenie, gdyż ich samorozwój i doskonalenie bez pozytywnego udziału osób trzecich (rodziny, terapeuty, instruktora) jest utrudnione.

Poniżej przedstawiam zestaw cech opiekuna/instruktora/reżysera, które mogą mieć pozytywny wpływ na rozwój twórczości osób z niepełnosprawnością intelektualną, mogą wspomóc, ułatwić i wytyczyć kierunek rozwoju twórczości; przeciwstawiam im zaś cechy, które stanowią zagrożenie dla samodzielnego rozwoju twórczego.

Tabela 1. Pozytywne vs. negatywne cechy opiekuna osób niepełnosprawnych intelektualnie

\begin{tabular}{|l|l|}
\hline \multicolumn{1}{|c|}{ Pozytywne cechy } & \multicolumn{1}{c|}{ Negatywne cechy } \\
\hline pobudzanie wyobraźni & narzucanie własnych wizji \\
\hline $\begin{array}{l}\text { przyglądanie się indywidualnym } \\
\text { preferencjom twórcy }\end{array}$ & $\begin{array}{l}\text { dobór technik uznanych przez } \\
\text { instruktora za najodpowiedniejsze }\end{array}$ \\
\hline $\begin{array}{l}\text { pobudzanie do poszukiwania } \\
\text { inspiracji w otaczającym świecie, } \\
\text { we własnym doświadczeniu }\end{array}$ & narzucanie tematu twórczości \\
\hline akceptacja rytmu pracy twórcy & praca "na akord” \\
\hline $\begin{array}{l}\text { szacunek dla samego procesu } \\
\text { tworzenia }\end{array}$ & $\begin{array}{l}\text { nastawienie na doskonały efekt } \\
\text { końcowy }\end{array}$ \\
\hline
\end{tabular}

Źródło: S. Pawlik, Drogi rozwoju talentu niepetnosprawnych intelektualnie artystów, [w:] Zbliżanie światów osób (nie-)petnosprawnych. Uwarunkowania, obszary, dobre praktyki, t. I, red. A. Stankowki, I. Wendreńska, Rużomberok 2013, s. 152.

Sposoby promocji. Umiejętne promowanie twórczości osób $\mathrm{z}$ niepełnosprawnością intelektualną może sprawić, że będzie ona dostępna dla szerszego grona odbiorców, co jest zjawiskiem pożądanym pod warunkiem, że zainteresowanie twórczością będzie wynikać z wartości samego dzieła, a nie z litości dla jego twórcy. Czesław Kosakowski zauważa:

[...] niepełnosprawność dotyczy autora, a nie dzieła, nie powinno się więc go postrzegać przez pryzmat przypadłości twórcy. Kryteria oceny powinny 
być jednakie dla twórców pełnosprawnych i tych z niepełnosprawnością. Pozbawienie równych szans to również forma dyskryminacji ${ }^{6}$.

Wytworu nie należy zatem traktować jako ubocznego efektu prowadzonej terapii. Twórczość dorosłych osób z niepełnosprawnością intelektualną wymaga osadzenia jej w szerszym, nie tylko terapeutycznym, kontekście. Wytwór (rysunek, rzeźba, spektakl), obdarzony cechami indywidualnego przekazu, jest wartością samą w sobie. Niejednokrotnie zadziwia i intryguje formą wykraczającą poza utarte schematy. Zetknięcie $\mathrm{z}$ takim dziełem może budzić w odbiorcy refleksję, zachwyt i wewnętrzną radośćn

Jak stworzyć odpowiednie warunki do spotkania z dziełem niepełnosprawnego intelektualnie artysty możliwie jak największej grupie odbiorców? Jest to zadanie niezwykle trudne. Wyjście z izolacji wymaga bowiem przełamywania wielu barier i ograniczeń tkwiących zarówno w środowisku społecznym, jak i w samych osobach niepełnosprawnych i ich najbliższym otoczeniu.

Aby działania promujące twórczość artystów z niepełnosprawnością intelektualną miały bardziej otwarty charakter, warto wyjść poza najbliższe otoczenie i szukać nowych, przyjaznych osobie niepełnosprawnej przestrzeni prezentacji (teatralnej, plastycznej), które są skierowane do szerokiego grona odbiorców. Coraz więcej miejsc związanych z kulturą (muzea, teatry, domy kultury) otwiera się na działania promujące sztukę osób z niepełnosprawnością i włączanie ich twórczości w główny nurt. Środowiska osób niepełnosprawnych muszą jednak wyjść z propozycją ciekawą, profesjonalną, skoncentrowaną na walorach twórczości osób z niepełnosprawnością intelektualną, a nie na samej niepełnosprawności.

${ }^{6} \mathrm{Cz}$. Kosakowski, Twórczość osób z niepetnosprawnościq - wielość spojrzeń, wielość problemów, [w:] Świat pełen znaczeń, red. J. Baran, S. Olszewski, Impuls, Kraków 2006, s. 26.

7 P. Rojek, P. Zatorski, Promocja sztuki osób z niepetnosprawnością intelektualną na przykładzie Warsztatów Terapii Zajęciowej UNIKAT, [w:] Artyści niepetnosprawni w życiu zawodowym i społecznym. Materiały pokonferencyjne II Konferencji NIKIFORY, red. B. Sochal, Fundacja Wspólna Droga, Warszawa 2009, s. 65. 
Podsumowując rozważania dotyczące promocji twórczości artystów z niepełnosprawnością, można wyróżnić kilka czynników mogących pozytywnie wpłynąć na obraz ich twórczości:

- szacunek dla wytworu artysty z niepełnosprawnością intelektualną, ze względu na wartość samego wytworu,

- jakość i profesjonalizm wykonania wytworu,

- jakość wydawanych materiałów promocyjnych,

- łamanie schematów, poszukiwanie nowych możliwości i przestrzeni dla promocji twórczości osób z niepełnosprawnością intelektualną,

- wyjście poza środowisko osób z niepełnosprawnością.

Środowisko. Najnowsze definicje niepełnosprawności intelektualnej zwracają uwagę na znaczenie kontekstu środowiskowego, w którym funkcjonuje osoba z niepełnosprawnością intelektualną.

Aktywność twórcza ma miejsce w szeroko pojętej rzeczywistości społecznej - dla twórczości osób z niepełnosprawnością intelektualną środowisko tworzenia i jego klimat jest warunkiem aktu twórczego $^{8}$. Chodzi o zbudowanie bezpiecznej przestrzeni, dostosowanej do rytmu aktywności twórczej osoby z deficytami.

Osoby z niepełnosprawnością intelektualną mają mniejszą siłę przebicia w zakresie działania twórczego' ${ }^{9}$. Zgodnie z ekologiczną koncepcją rozwoju twórczości, aby mogły one rozwinąć swoje predyspozycje i zdolności, niezbędne jest sprzyjające środowisko na wszystkich poziomach oddziaływań: począwszy od rodziny, szkoły, placówki pobytu, poprzez relacje między środowiskami, oddziaływania dalszych czynników, takich jak media, aż po system norm i wartości obowiązujących w społeczeństwie. W rozwoju twórczości poszczególne elementy przenikają się wzajemnie i współdecydują o sobie.

8 Ibidem, s. 23.

${ }^{9} \mathrm{H}$. Olechnowicz, Wyzwalanie aktywności dzieci głębiej upośledzonych umysłowo, WSiP, Warszawa 1994, s. 25. 


\section{Sztuka drogą włączania}

Świadomość społeczna decyduje o usytuowaniu osoby niepełnosprawnej w społeczeństwie. Inkluzja społeczna oznacza zatem poczucie przynależności do środowiska lokalnego, uczestnictwo w różnych przejawach kultury i ich przekształcanie, a także postawę akceptującą różnorodność osób z niepełnosprawnością i ich podmiotowość. Inkluzja polega na wypracowaniu nowego podejścia do osób niepełnosprawnych we wszystkich dziedzinach życia.

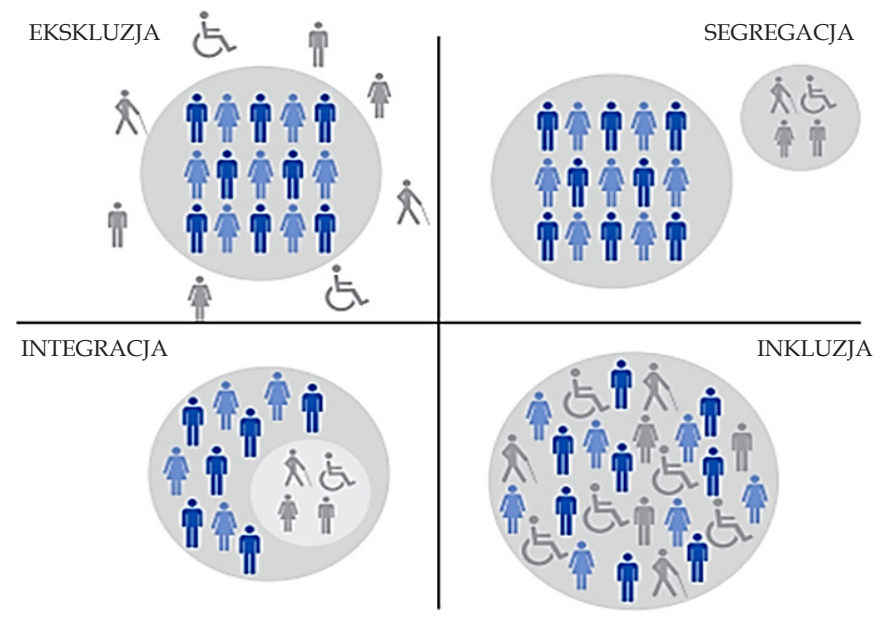

Schemat 2. Modele postaw społecznych Źródło: zasoby własne.

Powyższy schemat obrazuje postawy społeczne wobec osób z niepełnosprawnością - od wykluczenia osoby z niepełnosprawnością ze społeczeństwa, poprzez segregacje, integrację, aż po inkluzję.

Czterem zaprezentowanym postawom społecznym można przypisać postawy wobec twórczości osób z niepełnosprawnością:

- postawa niedopuszczająca osób niepełnosprawnych do procesu tworzenia, 
- postawa dopuszczająca istnienie twórczości tylko jako procesu związanego z arteterapią,

- postawa dopuszczająca istnienie twórczości osób z niepełnosprawnością, ale przy założeniu, że twórczość ta nigdy nie zyska szerokiego grona odbiorców,

- postawa nieróżnicująca twórczości na twórczość osób sprawnych i niepełnosprawnych.

Osoba niepełnosprawna intelektualnie dzięki twórczości rozumianej w sposób otwarty (postawa IV) ma szansę na wyjście poza ramy swojego niejednokrotnie zamkniętego świata i samodzielne kształtowanie swego społecznego wizerunku, a tym samym sposobu postrzegania jej przez środowisko społeczne. Twórczość jest więc ważnym czynnikiem wspierającym inkluzję społeczną osób $\mathrm{z}$ deficytami intelektualnymi. Sytuacje, w których osoby z niepełnosprawnością intelektualną mają możliwość wypowiedzi poprzez ekspresję artystyczną, mogą stać się "trzecią przestrzenią”, miejscem budowania innych niż dotąd relacji pomiędzy osobami sprawnymi i niepełnosprawnymi intelektualnie ${ }^{10}$. W sztuce jako miejscu spotkania światów możliwe jest pojawienie się nowych form społecznej solidarności oraz szansy na zacieranie się różnic między dwoma światami na rzecz wspólnego elementu, jakim jest język twórczości.

\section{Włączanie poprzez teatr}

Sztukę jako sposób włączania osób z niepełnosprawnością do społeczeństwa omówię na przykładzie działalności teatralnej. W jaki sposób teatr może stać się sposobem na przezwyciężanie społecznych barier w relacjach sprawny - niepełnosprawny?

Teatr jest sztuką najbardziej zespołową i wspólnotową ze wszystkich sztuk, oferującą nadzwyczajną jakość spotkania na wielu płasz-

${ }^{10}$ D. Krzemińska, Kod językowy i dyskurs osób z niepetnosprawnościa intelektualną. O bytowaniu na pograniczu, [w:] Świat pełen znaczeń, op. cit., s. 574. 
czyznach $^{11}$ - zarówno na płaszczyźnie wewnątrzgrupowej, jak i w relacji indywidualnej i zespołowej aktor - widz. Teatr nie istnieje bez swojego widza, jest interakcyjny ze swej natury.

Daje możliwość przełamania utrwalonych postaw psychospołecznych izolujących ludzi niepełnosprawnych, możliwość wyzwolenia ich z poczucia alienacji, samotności, bezradności ${ }^{12}$.

W tym kontekście warto odwołać się do koncepcji Teatru Uciśnionych (Theatre of the Oppressed) Augusta Boala, reżysera, aktywisty brazylijskiego, Koncepcja ta powstała w latach 70., w okresie dyktatury w Brazylii. Początkowo był to teatr politycznie zaangażowany; z czasem zaś stał się narzędziem zmiany społecznej w przeciwstawianiu się wszelkim formom dyskryminacji na tle kulturowym, płciowym, etnicznym, rasowym, seksualnym, politycznym, religijnym, ekonomicznym i historycznym.

Augusto Boal wykorzystał teatr jako narzędzie dialogu społecznego. Uważał, że każdy człowiek ma prawo do wyrażenia siebie poprzez sztukę. Teatr Uciśnionych to teatr społecznie zaangażowany, nastawiony na szukanie rozwiązań istniejących w naszych społecznościach opresji, mający wzmacniać demokrację i współdziałanie obywateli - członków społeczności.

Teatr Uciśnionych pozwala na włączenie do debaty społecznej szerszej grupy osób, w tym również tych, które często są marginalizowane. Pomaga szukać rozwiązań, które uwzględniają perspektywę każdego ${ }^{13}$.

Istnieje wiele światowych przykładów działalności teatralnej (Blue Teapot Theatre, Nalaga'at Center, Teatr RambaZamba) zmieniającej społeczną świadomość, gdzie teatr staje się miejscem, w którym niepełnosprawni aktorzy, mówiąc we własnym imieniu, sięgają do tematów uniwersalnych, zrozumiałych dla każdego człowieka,

\footnotetext{
11 I. Jajte-Lewkowicz, op. cit., s. 7.

12 Ibidem.

${ }^{13}$ www.stop-klatka.org.pl/teatr-ucisnionych ; www.hfhr.org.pl [10.04.2015].
} 
a w każdy z tych tematów - jak zauważa Justyna Sobczyk, reżyserka Teatru 21 - „wpisane są mechanizmy stygmatyzacji i wykluczenia”"14.

Blue Teapot Theatre jest profesjonalną grupą teatralną tworzoną przez 9 aktorów z niepełnosprawnością intelektualną. Przy Blue Teapot w 2010 r. powstała trzyletnia szkoła aktorska dla osób z niepełnosprawnością intelektualną (Performing Arts School), która umożliwia im uzyskanie certyfikatu Futher Education nad Training Awards Council (FETAC) w zakresie sztuk performatywnych. Założeniem Blue Teapot jest stworzenie miejsca do rozwoju twórczej tożsamości osób z niepełnosprawnością intelektualną oraz zmiana społecznej świadomości dotyczącej osób z niepełnosprawnością intelektualną dzięki medium, jakie stanowi teatr. Osoby z niepełnosprawnością intelektualną dzięki swojemu talentowi i kreatywności mają zatem szansę mówienia we własnym imieniu ${ }^{15}$.

Blue Teapot Theatre pojawia się na najważniejszych irlandzkich festiwalach teatralnych (Dublin Fringe Festival, Galeway International Arts Festival). Jego najczęściej nagradzamym spektaklem jest Sanctuary (Schronienie) - sztuka utrzymana w realistycznej konwencji, zbudowana ze „scenek z życia”, w których artyści poruszają temat seksualności osób z niepełnosprawnością intelektualną ${ }^{16}$.

Nalaga'at Center (z hebr. "dotknij”) to izraelski teatr tworzony przez osoby z dysfunkcją wzroku i słuchu, którego działalność dała początek innych przedsięwzięciom. W ramach Nalaga'at Center (organizacja non-profit) organizowane są warsztaty (język migowy, próbowanie wina w ciemności czy lepienie w glinie w ciemnościach), prowadzona jest restauracja Blackout pogrążona w całkowitej ciemności oraz kawiarnia Capish Cafe, obsługiwana również przez osoby niewidome i niesłyszace.

Początki Nalaga'at Center sięgają lat 90., kiedy artystka szwedzka Adina Tal została poproszona o poprowadzenie warsztatów teatral-

14 J. Sobczyk, O!swój: Podręcznik, wydanie internetowe: http://teatr21.pl/wp content/uploads/2015/02/podrecznik_oswoj.pdf.

15 http://www.blueteapot.ie/about-us [10.04.2015].

${ }^{16}$ J. Crawley, Dotknij, działaj, wtącz, http://www.ekonomiaspoleczna.pl/wiadomosc/1017636.html [10.04.2015]. 
nych dla osób z dysfunkcjami wzroku i słuchu. Jej teatralne poszukiwanie, uwieńczone zostało przygotowaniem pierwszego spektaklu Light is Heard in Zig Zag (Światło brzmi jak zyg zag), który pozwalał lepiej zrozumieć rzeczywistość osób niepełnosprawnych ${ }^{17}$.

Najważniejszym spektaklem Nalaga'at jest Not by Bread Alone (Nie samym chlebem), w którym jedenastu aktorów z dysfunkcją wzroku i słuchu zabiera publiczność w magiczną podróż do swego wewnętrznego świata ciemności, ciszy i... chleba. To uteatralizowana wersja doświadczenia, jakie mógłby wynieść gość restauracji Blackout. Od 2007 r. przedstawienie grane jest przy pełnej sali kilka razy w tygodniu ${ }^{18}$.

Teatr RambaZamba stanowi doskonały przykład zespołu integrującego ludzi sprawnych i z niepełnosprawnością intelektualną. Działa przy niemieckim Stowarzyszeniu Sonnenuhr (Zegar słoneczny). Jest to teatr z zawodowymi, zatrudnionymi na etatach, niepełnosprawnymi aktorami. Powstał w Berlinie w 1991 r. W ciągu kilku lat działalności z niszowego teatru przeobraził się $\mathrm{w}$ jedno $\mathrm{z}$ najciekawszych przedsięwzięć artystycznych związanych z osobami niepełnosprawnymi w Europie. RambaZamba nie uchyla się od trudnych, często kontrowersyjnych tematów. Dotyka trudnych kwestii społecznych i politycznych. Twórcy teatru (Gisela Höne i Klaus Ertorth, rodzice Moritza z zespołem Downa) chcą tworzyć teatr, „który dla odbiorców stałby się wyzwaniem artystycznym i intelektualnym, a dla aktorów - miejscem podporządkowanym ich wrażliwości, wyjątkowej ekspresji i wyobraźni, miejscem w którym czuli by się po prostu dobrze"19.

\section{Teatr 21}

W Polsce również podejmowane są próby przezwyciężania społecznych barier. Warszawski Teatr 21, grupa złożona z osób z zespo-

\footnotetext{
17 Ibidem.

${ }^{18}$ http://nalagaat.org.il/en/theater/ [10.04.2015]; J. Crawley, op. cit.

${ }^{19}$ K. Krawczyk, RambaZamba show, "Teatr" 2009, nr 1.
} 
łem Downa i autyzmem, zrodził się 10 lat temu z warsztatów teatralnych prowadzonych przez Justynę Sobczyk w Zespole Społecznych Szkół Specjalnych „Dać Szansę” w Warszawie. Zarówno reżyserkę, jak i aktorów interesowała wspólna, bardziej intensywna praca teatralna. Dziś w swoim dorobku mają kilka dużych spektakli teatralnych (m.in. Alicja, Portret, Ja jestem ja, I my wszyscy. Odcinek 0, Śmiertelnie trudna gra, Statek miłości. Odcinek 1). Teatr 21 wychodzi poza schematy funkcjonowania teatru niepełnosprawnych w Polsce, który swoje działania opiera głównie na „pospolitym ruszeniu” pasjonatów, którzy najczęściej są terapeutami w różnych ośrodkach zajmujących się niepełnosprawnymi ${ }^{20}$. Reżyserka i założycielka Teatru 21, wspólnie z 14 niepełnosprawnymi aktorami kreuje teatr profesjonalny, otwarty na nowe przestrzenie i środowiska. Grupa spotyka się na pozainstytucjonalnym gruncie, co gwarantuje im wolność artystyczną. Przestrzeni do prób i spektakli użycza Teatrowi 21 m.in. Teatr Powszechny w Warszawie oraz Instytut Teatralny. Justyna Sobczyk odmienność aktorów uważa za źródło ich tożsamości oraz doświadczenie budujące i stwarzające wyzwania. W swoich spektaklach próbują sięgać do tematów uniwersalnych. Reżyserka relacjonuje:

[...] opowiadamy o marzeniach konfrontowanych z rzeczywistością, o aspiracjach, o pracy, a w zasadzie o jej braku, o miłości, o pożądaniu, o przyjaźni, o rodzinie, o tradycji i jej ramach ${ }^{21}$.

Teatr $21 \mathrm{w}$ swoich poszukiwaniach relacji z publicznością idzie o krok dalej:

W nasze spektakle wpisana jest otwartość na Wasze oczekiwania, ale też na Wasz lęk. Nie boimy się go. Nasz twórczy niepokój nie pozwala nam zamknąć spektaklu przyjęciem braw. Chcemy z Wami rozmawiać także po wyjściu z teatru i tak często widzimy, że i Wy chcecie budować ten dialog22.

${ }^{20}$ http:/ / www.gloswielkopolski.pl/artykul/499089,teatr-niepelnosprawnychruchowo-i-intelektualnie,id,t.html [10.04.2015].

21 J. Sobczyk, op. cit.

22 Ibidem. 
Z poszukiwania przestrzeni dialogu między aktorami i publicznością zrodził się projekt "O!swój”. W projekcie prezentacji spektakli Teatru 21 na deskach warszawskich teatrów towarzyszy cykl warsztatów dla nauczycieli i animatorów pracujących z dziećmi i młodzieżą, dotyczących niepełnosprawności i problemu wykluczania. W pierwszej edycji projektu uczestniczyło ponad 30 nauczycieli i 2 tys. uczniów z warszawskich szkół. Obecnie realizowana jest druga edycja projektu. Justyna Sobczyk wierzy, że to właśnie teatr jest przestrzenią, w której możliwe jest oswajanie i wzajemne otwieranie się na siebie osób sprawnych i z niepełnosprawnością. Potwierdzeniem tego jest dla niej zaangażowanie i pozytywna reakcja uczestników projektu „O!swój”.

Warto zacytować niektóre wpisy Justyny Sobczyk na facebookowym profilu Teatru 21 - relacje pisane na gorąco, pełne pozytywnych emocji i wrażeń, które stały się udziałem grupy dzięki projektowi:

Portret - projekt O!swój: spotkanie-aktorzy-widzowie-pytania-odpowiedzirozmowa-wspólne bycie-radość:)

NASZ PIERWSZY BARTER! Co to się dzisiaj działo! Po spektaklu i rozmowie 21 postanowił nauczyć publiczność tańca Hula. Niespodziewanie otrzymaliśmy w zamian piękną pieśń! O!swój działa!

Jest też i inne doświadczenie, już nie tak pozytywne, ale nie mniej ważne zarówno dla młodzieży uczestniczącej w projekcie, jak i dla jego twórców:

Jedno z mocniejszych zdarzeń. Po dzisiejszym spektaklu wyszłam z Teatru Powszechnego $\mathrm{z}$ bombą $\mathrm{w}$ brzuchu, której tykanie słyszałam jeszcze długo po [...] Najpierw Daniel, będąc na scenie, w akcji krzyknął znacząco: Widownio! Kiedy usłyszał głośne komentarze!!! Potem przyszła kolej na monolog Teresy, która opowiada o miłości... Monolog jest niezrozumiały, to jej język, którego w większości my, nawet bliscy, słabo rozumiemy... Publiczność zaczęła się śmiać, a ten śmiech był tak głośny, tak nieznośny, nieprzerwany, że myślałam, że wbije mnie w ścianę [...] Teresa skończyła, ja wstałam i zaczęłam swój monolog... nie pamiętam słów [...] jedyne co wiedziałam, że to właśnie ta chwila, kiedy trzeba rozbić strukturę spektaklu, wejść na scenę, 
żeby potem nie musieć w złości pouczać młodych ludzi... To było ważne granie, ważne doświadczenie $\mathrm{w}$ oswajaniu...

Oswajanie z tematem inności, w tym wypadku niepełnosprawności, jest zadaniem trudnym. Ci którzy podejmują to wyzwanie, będą narażeni na krytykę, dezaprobatę, czasem wrogość, a nawet nienawiść.

Wypowiedź za pomocą języka teatru jest tylko jedną z możliwości przełamywania społecznych barier w relacji sprawny - niepełnosprawny, oddziałującą jednak z wielką siłą, dzięki angażowaniu całego człowieka - jego sfery przeżyć estetycznych, emocjonalnych i intelektualnych. Ukazują to doświadczenia teatrów: Blue Teapot, Nalaga'at, RambaZamba, Teatru 21. W teatrze osoby z niepełnosprawnością intelektualną mają szansę mówić własnym głosem, wypowiadać się w swoim imieniu. Teatr staje się wówczas „teatrem niezbędnym" ${ }^{23}$, w którym aktorzy w czasie odczas bezpośredniego spotkania z publicznością dostarczają swą pracą pożywienia myślom, emocjom i wrażliwości widzów - pożywienia, które jest niezbywalne i którego nie da się zastąpić innym rodzajem pokarmu. Not by bread alone ${ }^{24}$.

\section{Bibliografia}

Kosakowski Cz., Twórczość osób z niepetnosprawnościa - wielość spojrzeń, wielość problemów, [w:] Świat pełen znaczeń, red. J. Baran, S. Olszewski, Impuls, Kraków 2006.

KrZemiŃsKa D., Kod językowy i dyskurs osób z niepetnosprawnościa intelektualną. O bytowaniu na pograniczu, [w:] Świat pełen znaczeń, red. J. Baran, S. Olszewski, Impuls, Kraków 2006.

Olechnowicz H., Wyzwalanie aktywności dzieci głębiej upośledzonych umystowo, WSiP, Warszawa 1994.

PARYS K., Przestrzeń kreatywności uczniów z niepetnosprawnościa intelektualna w stopniu lekkim, Impuls, Kraków 2013.

${ }^{23}$ Nawiązanie do wykładu prof. dr. hab. Grzegorza Ziółkowskiego Peter Brookw poszukiwaniu teatru niezbędnego, http:/ / www.grotowski-institute.art.pl [10.04.2015].

${ }^{24}$ Tytuł wspomnianego wcześniej spektaklu Nalaga'at Theater. 
PAWLIK S., Drogi rozwoju talentu niepetnosprawnych intelektualnie artystów, [w:] Zbliżanie światów osób (nie-)petnosprawnych. Uwarunkowania, obszary, dobre praktyki, t. I, red. A. Stankowski, I. Wendreńska, Ružomberok 2013.

Rojek P., ZAtorski P., Promocja sztuki osób z niepetnosprawnościa intelektualna ma przykładzie Warsztatów Terapii Zajęciowej UNIKAT, [w:] Artyści niepetnosprawni w życiu zawodowym i spotecznym. Materiaty pokonferencyjne II konferencji NIKIFORY, red. B. Sochal, Fundacja Wspólna Droga, Warszawa 2009.

Terapia $i$ teatr. Wokót problematyki teatru ludzi niepetnosprawnych, red. I. Jajte-Lewkowicz, POS, Łódź 1999.

http:/ / www.nalagaat.org.il/en [10.04.2015]. http://www.gloswielkopolski.pl [10.04.2015].

http:/ / www.ekonomiaspoleczna.pl [10.04.2015].

http://teatr21.pl/ [10.04.2015].

http:/ / www.blueteapot.ie [10.04.2015].

http:/ / stop-klatka.org.pl [10.04.2015].

http://www.grotowski-institute.art.pl [10.04.2015]. 